3. Цинк i COVID 19: що відомо на початок 2021року? Інтернетpecypc: https://health-ua.com/article/63510-tcink-COVID19-sho-vdomonapochatok-2021roku

4. Chemistry of Europe's Agricaltural Soils (2014) / L. Reimann, M. Birke, A. Demetriades, R. Filzmoser, P. O`Conner. Hannower: BGR. Part A. 528 p.

5. Геохімічний атлас грунтів України: масштаб $1: 5000 \quad 000$ (за результатами міжнародного проекту GEMAS) /B.P. Клос та ін. Київ: ДП «Українська геологічна компанія». 2015. 94 с.

6. Авцын А.П., Жаворонков А.А., Риш М.А., Строчкова Л.С. Микроэлементозы человека: этиология, классификация, органопатология. Москва: Медицина, 1991. 496 с.]

7. Короновірусна хвороба 2019 року в Україні. Інтернет-ресурс: https://uk.wikipedia.org/wiki/Коронавірусна_хвороба_2019_в_Україні

DOI https://doi.org/10.30525/978-9934-26-111-4-15

\title{
ECOLOGICAL COMPONENT OF ADVENTIVE ELEMENT OF KHARKIV URBAN FLORA (UKRAINE)
}

\author{
Zviahintseva K. O. \\ PhD, Assistant Professor, \\ Department of Botany and Plant Ecology \\ V. N. Karazin Kharkiv National University \\ Kazarinova H. O. \\ PhD, Assistant Professor, \\ Department of Botany and Plant Ecology \\ V. N. Karazin Kharkiv National University \\ Kharkiv, Ukraine
}

Adventive plant species cause changes in all structures of urban flora, including ecological. The expansion of the range of habitats and the strengthening of the role of adventive plants in the structure of plant communities indicates an increaseofinvasive potential of introduced species over the years.

The ecological analysis of adventive fraction of Kharkiv urban flora was processed using the classifications of R. Wittig et al. (degree of 66 
urbanization) [6, p. 265-282] and J. Jalas (degree of hemerobia) [4, p. 1-15]. Analysis of distribution of adventive plant species in the vegetation classes was performed by processing geobotanical descriptions of urban vegetation in the programs Turboveg 2.91 [3, 78 p.] and Juice 7.0.127 [5, 98 p.]. The obtained phytocenones have been identified by Prodrome of The Vegetation of Ukraine [2, 784 p.], habitat types - by National Habitat Catalogue of Ukraine [1, 442 p.].

After analyzing the adventive plant species by distribution, we have found that 136 species $(39.7 \%)$ occur sporadically throughout the city and represent a stable component of transformed habitats. The distribution of other species of adventive plants is as follows: 69 plant species (20\%) grow locally in some parts of the city, 62 plantspecies (17.9\%) are widespread in the city,78 plant species $(22.3 \%)$ was accidentally found (from 2 to 5 localities).

The distribution of adventive plant species according to the city zoning shows the predominance of plants of urban and suburban zones (208 species; $60.6 \%)$. Wehave found 94 plant species $(27 \%)$ ofurban zone that grow exclusively in synanthropicecotopes. Other 43 plant species $(12.4 \%)$ have been found in the city outskirts with a decrease in the degree of urbanization. Thus, wenote an increase in number of adventive plants from the periphery to the city center, where the main centers of introduction are located.

According to the analysis of vegetation we have established the distribution of plant communities of Balloto nigrae-Robinion pseudoacaciae Hadačet Sofron 1980, Chelidonio majoris-Robinion pseudoacaciae Hadač et Sofron ex Vítková in Chytrý 2013, Chelidonio-Acerion negundi L. Ishbirdina et al. invalid. (art. 3o, 5), Geo-Acerion platanoidis L. Ishbirdinaet A. Ishbirdin1991 nom. invalid. (art. 3o, 5) associated with anthropogenic broad-leaved forests habitats. Vegetation of nutrient-demanding ruderal herbaceous habitatsis represented by Convolvulo arvensis-Agropyrion repentis Görs 1967, Arction lappae Tx. 1937 communities. Plant communities of Sisymbrion officinalis Tx. et al. ex von Rochow 1951, Panico-Setarion Sissingh in Westhoff et al. 1946 form nutrientdemanding ruderal annual and biennial species habitats, Onopordion acanthii $\mathrm{Br}$.-Bl. et al. 1936 -habitats of ruderal annual and biennial species on nutrient-poor soil. Plant communities of nitrophilous annual vegetation of muddy river banks are represented by Senecionion fluviatilis Tx. ex Moor 1958, Bidention tripartitae Nordhagen ex Klika et Hadač 1944, Chenopodion rubri (Tx. in Poli et J. Tx. 1960) Hilbig et Jage 1972.

To determine the participation of species by the degree of hemerobia [2, p. 1-15], all non-native species were divided according to their occurrence in anthropogenic ecosystems. The majority of species $(106 ; 30.6 \%)$ belong to the group ofmeso-, eugemerobes (Alcea rosea L., 
Amaranthus albus L. etc.). They are the components of flora with a high degree of anthropogenic load. Euhemerobes (87 species; 25\%) and mesohemerobes $(82 ; 23.8 \%)$ associate with transformed ecosystems and culture phytocenoses (Bryonia alba L., Fraxinus pennsylvanica Marshall, Aristolochia clematitis L., Fumaria schleicheri Soy.-Willem., Ligustrum vulgare L., Rosa rugosa Thunb. etc.). The areas of the city with human activity asa limiting factor arecenters of expansion of adventive plant species or formation of synantropic plant communities. Such species are part of meso-, eu-, polyhemerobes $(30 ; 8.8 \%)$ and polyhemerobes $(15 ; 4.4 \%)$ groups. They grow on anthropogenically transformed ecotopes in the urban zone (Acer negundo L., Parthenocissus inserta (A. Kern.) R. M. Fritsch, Consolida regalis S.F. Gray, Cannabis ruderalis Janisch. etc.). In areas within significant human impact on ecosystem, we found few adventive plant species (Oenothera rubricaulis Klebahn., Vicia villosa Rothetc.). The explanation may be increase of oligohemerobes $(12 ; 3.5 \%)$ in the city's suburban zone. Other groups areoligo-, mesohemerobes (11 species; 3.2\%), eu-, polyhemerobes ( 1 species; $0.3 \%)$ and meso-, oligohemerobes ( 1 species; $0.3 \%$ ). The conducted research of degree of hemerobicity of the adventive fraction of urban flora confirmed the high level of transformation and urbanization of the city's flora. All groups of hemerobia are typical for ecosystems with active or weak human activity. In particular, this is confirmed by the absence of stenotic group of ahemerobes, which represents only natural ecosystems.

\section{References:}

1. Національний каталог біотопівУкраїни / за ред. А.А. Куземко, Я.П. Дідуха, В.А. Онищенка, Я. Шеффера. Київ: ФОП Клименко Ю.Я., 2018. 442 c.

2. Дубина Д.В., Дзюба Т.П., Смельянова С.М. та ін. Продромус рослинності України. Київ: Наук. думка, 2019.784p.

3. Hennekens S. Turboveg for Windows. 1998-2007. Version 2. 2008. $78 \mathrm{p}$.

4. Jalas J. Hemerobe und hemerochore Pflanzenarten. Einterminologischer. Reformver such. Acta. Soc. Fouena Flora Fenn. 1955. 11(72). P. 1-15.

5. Tichý L., Holt J.JUICE: Program for management analysis and classification of ecological data: Program manual. Brno: Vegetation Science group. $2006.98 \mathrm{p}$.

6. Wittig R., Diesing D., Godde M. Urbanophob - Urbanoneutral Urbanophil. Das Verhalfen der Artenge genuber dem Lebens raum Stadt. Flora. 1985. 177 (5-6). P. 265-282. 